\title{
EDUCATION, INFORMATION ETHICS AND EMOTIONS DURING THE DEVELOPMENT OF THE DIGITAL ECONOMY
}

\author{
Olga Shmyreva \\ Candidate of Psychology Sciences, Associate Professor, Voronezh State University of Engineering \\ Technologies, Revolution Avenue,19, Voronezh, Russia, \\ E-mail: oishmyreva@rambler.ru
}

\begin{abstract}
The article shows the problems of education during the development of the digital economy. Information ethics has a positive impact on the formation of the digital economy. In the context of total digitalization, the development of information ethics and the desire to achieve emotional balance will help to increase the stability of the personal potential of participants in the educational process. In pedagogical activity, emphasis should be placed on the emotional potential of teachers and students for solving pedagogical problems. A promising direction in education is the use of neuromarketing technologies.
\end{abstract}

Keywords: education, information ethics, emotions, pedagogical activity, neuromarketing, digital economy.

\section{INTRODUCTION}

Education as a factor in human development throughout life continues to attract the attention of scientists. Changes in human capital in the light of the transition to a new reality require constant modernization of education. Education defines both the essence and the process of personal and social development, being a means of consciously building not only a professional, but also a life path. Interest in a person, the formation of his inner world and control of the dynamics of the latter are a reflection of the need for the conscious construction of society, control of events and social relations.

The events of recent months on a global scale have shown that society as a whole is not ready for restrictions on various freedoms, in particular, movement, compliance with the self-isolation regime and other prescribed rules.

In the era of global digitalization and the coronavirus pandemic, education and human resources are highlighted in a new perspective: the task is to prepare a person for biological survival and health preservation, unexpected lifestyle changes and reorientation of thoughts to a different plane. A person is still required to constantly improve and expand the range of competencies, to have advantages over artificial intelligence, and at this time adaptability to limitations is coming to the fore.

The formation of research competencies and technical foundation, information structure and information security are the vectors of economic and educational development. The goals of education are to create key conditions for training the digital economy, improve the education system to provide competent personnel for the labor market, taking into account the requirements of the digital economy, create a motivation system for mastering the necessary competencies and participation of personnel in the development of the digital economy (Endovitsky DA, Durakova IB, 2018), (Belenov O.N., 2019). The question naturally arises about the advisability of changing the ethical plane of public life as an important aspect of people's behavior in the context of the formation of the digital economy.

In intellectual terms, the task of shaping and developing the flexibility of the intellect in general and individual cognitive functions in particular is quite clear in the near future. In the spiritual and mental spheres, it is necessary to change the perspective depending on the dynamics of society's needs in the sphere of spiritual 
reproduction, fluctuations in the mindset and the current mental state of people. It seems that at the moment, too, deficient personality traits are exposed, at first glance, strong-willed, which include endurance, discipline, patience, responsibility, and a sense of duty. However, a full-fledged transition to a new type of education makes us deeply revise the philosophy of education. Is a person ready to give up the status of the central element of the universe and start taking care of nature, resources, return to realizing the value of the spiritual sphere of society and maintaining it as guidelines for life and education?

\section{METHODOLOGY}

The methodological basis of the study was made up of: general scientific principles: dialectical logic (contradictions, consistency, unity of analysis and synthesis, ascent from the abstract to the concrete, comprehensive consideration); principles of research complexity and complementarity; empirical methods: literature analysis, document analysis, comparison and grouping method, interpretation. Together, they provide an opportunity to study the state and development opportunities of modern education from various angles.

The theoretical basis was the work of domestic and foreign scientists developing concepts for the development and improvement of the education system, information ethics, the concept of cognitions and emotions, during the formation and development of the digital economy.

\section{DISCUSSION}

Modern civilization as a form of cultural and historical integrity is characterized by its own system of moral values. Total life changes create new problems that require not only political, economic, but also moral, ethical, and psychological solutions.

A mixture of technologies of the physical, digital and biological worlds took place, as a result of which new opportunities and influences appeared on political, social and economic systems, as well as on the spiritual sphere of society. A person is forced to create artificial intelligence, serve it and compete with it, defending his high, in the recent past by historical standards, status. Anthropocentrism, obviously, is losing its leading position in the worldview attitudes of people around the world: the insubordination of nature to man as the center of the universe, the depletion of the planet's resources, competition with artificial intelligence and the fight against viruses lead to an awareness of the fragility of human life and the achievements of civilization. The fashion for freedom of expression and creativity as a form of development is replaced by the fashion for giving up some of the freedoms and striving for frames.

The sphere of high technologies and computer information contributes to the substitution of computer functions for numerous types of activities previously inherent in humans. Coverage - from transport, medicine, communications, education, banking, industry, e-commerce to services and everyday life. The dominance of technology has a strong impact on all spheres of public life, including spiritual and moral, political, socio-economic life, and the psyche of people. To comprehend these phenomena, information ethics is actively developing as a branch of traditional ethics, a process and result of its transformation.

Total digitalization creates problems in the labor market, entails the reduction and even disappearance of a number of professions in a short time, which significantly complicates social adaptation. There is also a problem of fair access to the achievements of the "digital revolution", the number and scale of new types of discrimination are increasing. Taken together, these trends serve as a solid foundation for social inequality and the growth of social tension (Guryanova, A. V., et al., 2020). Independent actions and manifestations of one's own personality in the global information space often lead to the launch of criminal actions in the information environment. Representatives of the growing generation often have a feeling of impunity for their own actions, in part, due to virtual, rather than real, contact with society.

Also, in the information space, it becomes more difficult to control the actions of each individual person to comply with the specified standards. In the global information space, there are practically unlimited opportunities for moving through networks of various information, without notifying the owners. The society is not sufficiently prepared to regulate interactions in the information space, in accordance with the ethics of moral and ethical norms and principles.

Moral norms, as laws of human community, should stand on the protection of the individual and ethnic community in the process of their interconnection and interdependence of development. Reconciliation of the interests of society and the individual is still an urgent task; education should contribute to its resolution.

After determining the spiritual and moral needs of society and analyzing the current situation, finding mistakes and gaps in development, setting educational guidelines, you can proceed to the search for 
educational resources and means.

The world is steadily moving towards virtual reality. For a quick transition of a person to a new mode of functioning, it is advisable to more widely and quickly master and apply the achievements of neurosciences, in particular, neuromarketing technologies. At the same time, the movement of the world towards virtual reality increases the risk of deformation of the psyche, which society has not yet learned to prevent and regulate. In theory, the use of neuromarketing in education can and should increase the effectiveness of traditional methods. The distance learning format and the lack of live communication are accompanied by a decrease in the emotional component of the pedagogical process. What mental phenomena can be used to optimize cognitive activity in the new educational environment?

The psychological approach to education is based on the use of the energy of emotions for human development. Emotional development coordinates activity characteristics in many areas of personality activity (Shmyreva O., Revista Inclusiones, 2020).

It is known that pedagogical activity is creative, in its essence, the emotional component serves as a fulcrum for it. Emotions serve as a form of assessing events and phenomena, as well as the energy component of any action. The emotional component is the personal resource of each participant in the educational process - teachers and students. Given the creative nature of pedagogical activity, it is advisable to use the energy of emotions to solve pedagogical problems.

It is known that creative problem solving includes a number of stages. At the contemplative-explanatory stage of solving a creative problem, the measure of the difficulty of the creative problem and the depth of the contradiction contained in it are involuntarily tested, and even a solution can be found - during interpretation. At the second - empirical stage - the search will continue in the mode of intuitive thinking, the emotional component plays a significant role in this. An intuitive solution is typical for all types of human creativity (Shmyreva O., Revista Inclusiones, 2020), including pedagogical. At the same time, the transformation of emotional energy into creative occurs.

An additional argument in favor of using emotions as an educational resource is understanding the characteristic feature of the modern digital economy - the experience economy. Education during the development of the digital economy should be based on neuromarketing. Neuromarketing techniques make it possible to monitor the state of a person's consciousness in the interval from the moment the information is presented to the appearance of a response to it; in the work of consciousness, two conditional stages can be distinguished: the first stage is the perception of stimuli followed by a reaction, the second is the decisionmaking process. The process of thinking as a nervous activity can arise under the influence of sound, touch, movement, background feelings (mood, emotions), peripheral images, color (Zhunina V.I., 2018).

As you know, the novelty of a stimulus - in this context - impressions - helps to attract and retain attention on the object being cognized. The effect of sympathy for the stranger associated with a "mistake", or rather, the brain's hint in assessing a new situation with success can precede productive activity in changing conditions (Markovitch, N., Netzer, L., \& Tamir, M., 2017). Therefore, attention management should rely not only on sensory stimulation, but also on emotions (Aldao, A., \& Nolen-Hoeksema, S., 2013), (Danielsson, M., \& Bengtsson, H., 2016), (Scott H. Hemenover \& Colin R. Harbke. 2020). Neuromarketing is anti-dogmatic, open and universal (Leskova E.D., 2019). Neuromarketing technologies are used as effective modeling tools in education (Ababkova M., 2017), (Kaplunov D., 2017).

In making important strategic decisions in the field of education, it is important to take into account the experience of other countries. The influence of the psychological factor on the functioning of the training platform in the digital economy has been scientifically substantiated. Thus, in the work of Ch. Kreidl, U. Dittler systematized ideas about the competitiveness of a graduate of higher education from the standpoint of employers in Europe, showed that the use of digital services and communication devices by students in the classroom creates significant obstacles that complicate the formation of the required competencies (for example, educational institutions in Germany, the Netherlands and Switzerland). The dense flow of information in the process of communicating with the "network" in $40 \%$ of cases is a serious obstacle to classes (Kreidl Ch., Dittler U., 2018). This study shows that for the formation of modern methodological competencies of students, it is logical to use digital technologies, taking into account the intragenerational expectations and values of young people, that is, psychological components. There is an overload of the operative memory with homogeneous information, concentration of attention decreases, and it becomes difficult to solve educational problems. In our opinion, the combination and / or alternation of information load with emotions will contribute to the optimization of the educational process. Consideration should be given to the positive effects of emotions on cognition and motivation (Ford, B.Q., \& Tamir, M., 2014). 
Investing in human potential should be the driving force behind the development of society and education (Endovitsky D.A., Durakova I.B., 2018), (Belenov O.N., 2019).

\section{RESULTS}

The enduring value of nature and man as a part of it should be of incomparably greater value in any society wishing to prosper than technology and artificial intelligence. Errors and miscalculations in the formation of the worldview, the intellectual capabilities of society may have various reasons that need to be identified and analyzed in a timely manner.

In accordance with the requirements of information ethics, increasing the stability of personal potential by achieving emotional balance in the context of total digitalization initially involves reducing the risks of increasing social inequality and growing social tension, and only then - improving the quality of training of specialists in the field of information and communication technologies. Mentality and psychological attitudes in certain cases slow down the formation and development of economies.

Analysis of information sources led to the following conclusions.

1) In the world community, the attitude towards all types of education is changing, and it becomes clear that it cannot be narrow-profile, aimed at social, technical or economic progress (Afanasenko I.D., 2018).

2) Information ethics is the driving force behind the development of the digital economy (Shmyreva O.I., RuDEcK, 2020).

3) Emotions are an educational resource, the emotional factor acts as the potential of the subjects of the educational process - teachers and students (Shmyreva O.I., RuDEcK, 2020).

4) A creative solution to a pedagogical problem can be obtained at the contemplative-explanatory stage during interpretation (Shmyreva O., Revista Inclusiones, 2020).

5) Education during the development of the digital economy should use neuromarketing technologies (Ababkova M., 2017), (Zhunina V.I., 2018), (Kaplunov D., 2017), (Leskova E.D., 2019).

\section{CONCLUSION}

Pedagogical activity in any conditions, regardless of the current situation in society, relies on the potential of emotions of participants in the educational process. The transformation of emotions into creative activity contributes to the solution of educational problems. Management of students' attention, as well as in general, the creative activity of teachers is impossible without an emotional component, emotions act as effective means of modeling behavior in education.

The driving force of education in the context of innovative transformations of society and the economy is the contradiction between the needs and capabilities of society in the implementation of educational technologies, the emotional factor acts as the potential of the subjects of the educational process, and information ethics is a factor in the development of the digital economy.

\section{REFERENCE LIST}

Ababkova M. (2017). Neuromarketing technologies in education. Moscow: Foundation for the

Development of Conflictology. 290 p. (in Russ).

Afanasenko I. D. (2018). Digital economy and social and ethical values. Izvestia SPbGEU. №. 5 (113), Pp. 7-11. (in Russ).

Aldao, A., \& Nolen-Hoeksema, S. (2013). One versus many: Capturing the use of multiple emotion regulation strategies in response to an emotion-eliciting stimulus. Cognition and Emotion, 27. Pp. 753-760. DOI: https://doi.org/10.1080/02699931.2012.739998 (in Engl).

Belenov O.N. (2019). Digital competences of heads of marketing departments. Vestnik VSU. Series "Economics and Management". № 3. Pp. 93-99. (in Russ).

Danielsson, M., \& Bengtsson, H. (2016). Global self-esteem and the processing of positive information about the self. Personality and Individual Differences, 99. Pp. 325-330. DOI: 
https://doi.org/10.1016/j.paid.2016.05.014 (in Engl).

Endovitsky D.A., Durakova I.B. (2018) Statistical analysis as the Basis for the Practice of Modernizing Personnel Management: International Experience. International Journal of Engineering and Technology (UAE). T. 7, № 4.38. Pp. 145-151. https://doi.org /10.14419/ijet.v7i4.38.24341 (in UAE).

Ford, B.Q., \& Tamir, M. (2014). Preferring familiar emotions: As you want (and like) it? Cognition and emotion. Vol. 28. Issue 2. Pp. 311-324. DOI: https://doi.org/10.1080/02699931.2013.823381 (in Engl).

Guryanova, A. V., et al. (2020). "Socio-ethical problems of the digital economy: challenges and risks." Digital Transformation of the Economy: Challenges, Trends and New Opportunities. Springer, Cham. Pp. 96102. (in Engl).

Kaplunov D. (2017). Neurocopywriting. 100 methods of influence with the help of text. M: Publishing house "E". 352 p. (in Russ).

Kreidl Ch.,Dittler U. (2018). Wo stehen wir? Ergebnisse einer umfassenden empirischen Studie zu Lernen und Unterricht an Hochschulen heute In: Hochschule der Zukunft. Beiträge zur zukunftsorientierten Gestaltung von Hochschulen. Kreidl Ch.,Dittler U. (Hrgs.). Springer Fachmedien, Wiesbaden GmbH. 307 p. (In Germany).

Leskova E.D. (2019). Ethical application of neuromarketing technologies. Scientific Notes of PNU, №. 1. Pp. 250-256. (in Russ).

Markovitch, N., Netzer, L., \& Tamir, M. (2017). What you like is what you try to get: Attitudes toward emotions and situation selection. Emotion, 17(4). Pp. 728-739. DOI: https://doi.org/10.1037/emo0000272 (in Engl).

Scott H. Hemenover \& Colin R. Harbke. (2020). Individual differences in motives for regulating affect intensity: positive trait affect and the value of trait-consistent affect. Cognition and emotion, Vol. 28. DOI: https://doi.org/10.1007/s11031-020-09844-4 (in Engl).

Shmyreva O. (2020) Transformation of emotions into creatiyity as a way of solving problems. Revista Inclusiones. Volumen 7. Pp. 464 - 476. (In Chile).

Shmyreva O.I. (2020) Information Ethics as a Factor in the Development of the Digital Economy. Proceedings of the Russian Conference on Digital Economy and Knowledge Management. Series: "Advances in Economics, Business and Management Research». Atlantis Press. https://dx.doi.org/10.2991/aebmr.k.200730.112 (in Engl).

Zhunina V.I. (2018) Modern neuromarketing: features and prospects of application. Economics. State. Society (Electronic Journal of Scientific Publishing for Students and Young Teachers of the Penitentiary Institution of the RANEPA). № 2 / http://ego.uapa.ru/ru/issue/2018/02/7/ (in Russ). 